\title{
Nanotechnology and the US national innovation system: continuity and change
}

\author{
David C. Mowery
}

Published online: 11 February 2011

(C) The Author(s) 2011. This article is published with open access at Springerlink.com

\begin{abstract}
A substantial literature on nanotechnology innovation and commercial development has characterized several elements of these phenomena as constituting new developments in the US national innovation system. Among these elements are the (asserted) "post-academic" nature of US universities' involvement with nanotechnology $\mathrm{R} \& \mathrm{D}$, and federal funding of nanotechnology R\&D on goals related to economic competitiveness. This paper challenges the "novelty" of these elements, while suggesting that other elements of nanotechnology $\mathrm{R} \& \mathrm{D}$, including the extensive patenting of the results of nanotechnology-related research and the emphasis within many university-industry collaborations on patent-based channels for "technology transfer," may indeed be new and raise questions for the long-term efficiency and innovative performance of nanotechnology-related R\&D.
\end{abstract}

Keywords Nanotechnology · National innovation system · US R\&D policy · University-industry collaboration

JEL Classification $\mathrm{O} 3 \cdot \mathrm{O} 5$

\section{Introduction}

The development of nanotechnology has spawned a large body of research on the economic and societal implications of this new technology. Much of this literature argues that nanotechnology research represents a "New Wave" of public policy and inter-institutional relationships in the US national innovation system, a concept that I define in greater detail below. At least two elements of novelty are cited by proponents of the "new wave" characterization (for one representative account, see Johnson 2004): (1) Federal R\&D funds are focused on economic objectives, rather than supporting fundamental research

\section{C. Mowery $(\bowtie)$}

Haas School of Business, U.C. Berkeley \& NBER, S545 Haas School of Business \#1900,

University of California, Berkeley, Berkeley, CA 94720-1900, USA

e-mail: mowery@haas.berkeley.edu 
aimed at advancing knowledge; and (2) the policies adopted by US universities in nanotechnology research represent a new form of "post-academic research," emphasizing the commercialization of discoveries through licensing of academic patents.

In fact, however, the features of nanotechnology research cited in the previous paragraph are not novel. Although the policies and institutions within which nanotechnology research is carried out display some novel features, there are also important continuities in US public policy and in the ways in which US universities have supported innovation in nanotechnology. It seems important to focus on the elements of genuine novelty, rather than emphasizing those that are of secondary importance, and I undertake such an analysis in this brief survey.

\section{The US "national innovation system"}

The "national innovation system" framework for analyzing innovative performance and policy has been an influential area of scholarship for more than 20 years, since the first articulation of the concept in Freeman (1987; see also Lundvall 1992 and Nelson 1993). "National" innovation systems typically include the institutions, policies, actors, and processes that affect the creation of knowledge, the innovation processes that translate research into applications (either for commercial sale or deployment in such "nonmarket" contexts as national defense), and processes and institutions that influence the adoption of innovations. As such, the US national innovation system includes not just the institutions performing $R \& D$ and the level and sources of funding for such $R \& D$, but policies—such as antitrust policy, intellectual property rights, and regulatory policy-that affect technology development, the training of scientists and engineers, and technology adoption. Institutions and policies ranging from national systems of higher education to corporate finance and governance also are important components of national innovation systems.

Arguably, the US "national innovation system" is not national, since important influences on it span national borders; it clearly deals with much more than "innovation" alone; and the complex and weakly coordinated interaction of public and private institutions within it defy definitions of a "system" that imply planning or purposive design. Nevertheless, the innovation system concept remains relevant and useful as a heuristic device for highlighting elements of continuity and change in US nanotechnology policy and institutions.

\section{Nanotechnology: a "new wave" within the US national innovation system?}

The social science literature on nanotechnology has highlighted several elements of innovation-related processes and policies as significant departures from the historic structure of the US national innovation system. According to proponents of this argument, the "new wave" is most apparent in the characteristics of federal-government funding of nanotechnology $\mathrm{R} \& \mathrm{D}$ and in the inter-institutional relationships that characterize nanotechnology R\&D and innovation.

In this view, the major US federal government interagency program for support of R\&D in nanotechnology, the "National Nanotechnology Initiative" (NNI), represents a significant break with the philosophy underpinning federal support of R\&D in industry and especially, academia since 1945. For most of this period, supporters of the "new wave" argument contend, federal funding of science emphasized basic research and granted autonomy to academic scientists in establishing their research priorities. The architect of 
this approach to R\&D funding was Vannevar Bush, author of the famous 1945 report, Science-The Endless Frontier. Bush's argument, elaborated in economic terms by postwar economists such as Nelson (1959) and Arrow (1962), justified public funding of such research as necessary because of the inability of private industry to capture the economic returns from these investments. Government support of fundamental research thus addressed a key "market failure" in industrial economies and was essential to expand the knowledge base that indirectly aided industrial innovation.

The NNI has transformed the terms of this "social contract," according to some scholars. Johnson (2004) and McCray (2005) argue that the NNI's support of research in universities is an example of "post-academic research":

This regime is characterized by an emphasis on the utility of science and the enlistment of academic research as a 'wealth-creating technoscientific motor for the whole economy,' views clearly expressed in the documents and testimony supporting the NNI... While the end of the Cold War is certainly relevant, the changing nature of research funded by the federal government and conducted at universities is even more significant. Since the passage of the Bayh-Dole act in 1980, the 'triple helix' of relations between the academy, industry, and government has been significantly altered and strengthened...The borders between science and technology, as the NNI implementation plan shows, have blurred while the commercialization of academic science has become a key driver for its funding. (McCray 2005, p. 192). ${ }^{1}$

In this view, public funding of academic $R \& D$ in nanotechnology now is motivated by an interest in economic outcomes, rather than a commitment to advancing fundamental knowledge. Partly because of this emphasis on innovation-related results, the NNI also emphasizes university-industry collaboration and "technology transfer," characteristics of research organization and policy that some scholars refer to as "Mode 2" (Gibbons et al. 1994) while others highlight the emergence of a "Triple Helix" of inter-institutional collaboration that spans industry, government, and universities (Etzkowitz 2008).

The premise of this characterization of nanotechnology $R \& D$ as constituting a new "social contract," however, relies on an inaccurate characterization of the earlier period. Although the market failure rationale retains rhetorical influence as a justification for public R\&D investments, its influence over these investments has long been modest. Most OECD nations' R\&D investment budgets are dominated by programs that serve specific government missions, such as defense, agriculture, health, energy, and other activities. The "market failure" rationale underpins less than $50 \%$ of public R\&D spending in most of these economies. ${ }^{2}$ The United States is an outlier, with large R\&D programs in defense and

\footnotetext{
1 "In the 1950s and 60s, science and technology policy was guided by the 'pipeline' model of the relationship of science to technology championed by Vannevar Bush ... In this scheme, federally funded basic science would provide the new knowledge that underpinned new technological developments. Government spending needed to focus on basic, non-targeted research because this kind of scientific work was both fundamental and less attractive to the private sector ... As economic circumstances worsened after 1973, policy makers wanted to demand more economic bang for their research buck. American scientific research had to be part of the solution: American scientific superiority needed to translate into economic performance. But to do so, the role of the federal government had to change, and these changes took over a decade to put into place...

...the focus of much federal science and technology policy in the 1980 s was on problems in the movement and translation of knowledge from the lab through development into the market" (Johnson 2004, p. 219).

2 Data from the National Science Foundation (National Science Board 2006) on "mission-oriented" and "nonmission-oriented" R\&D spending for six industrial economies (Germany, Japan, France, the United Kingdom, Canada, and the United States) and one middle-income industrializing economy (South Korea)
} 
health bringing the total "mission-oriented" R\&D budget to over $90 \%$ of federal-government R\&D spending. Also noteworthy is the relatively small share of central-government R\&D spending accounted for by the "Bush-Arrow" form of R\&D spending, nonmission-oriented R\&D. This class of public R\&D investment accounts for nearly $30 \%$ of reported central-government R\&D spending in France and Germany, but is well below $20 \%$ in the United Kingdom and Canada, and barely exceeds 5\% in the United States.

The large mission-oriented R\&D programs supported by public funds in the post-1945 United States have yielded important economic benefits. Much of the innovation underpinning electronics and information technology (IT), ranging from semiconductor components to computer software and the networking technologies that led to the Internet, was supported by Defense Department funds allocated to industrial and academic researchers (See Mowery 2010a, b). Similarly, the competitive strength of the postwar US pharmaceuticals and medical devices industries, as well as the growth of biotechnology, owe a considerable debt to R\&D funded by the federal government through the National Institutes of Health (Mowery et al. 2009).

The governance of many of these large public investments in mission-oriented R\&D also bears little resemblance to the idealized portrait of the "[Vannevar] Bush social contract" 3 articulated in Guston and Keniston (1994). Rather than "scientists" controlling the allocation of public R\&D funds, allocation decisions in these R\&D programs were based on assessments of the research needs of specific agency missions ranging from national defense to agriculture. ${ }^{4}$ Although Gibbons et al. (1994) argue that "Mode 2" R\&D is novel because it is multidisciplinary, motivated by societal needs, and accountable to public funding agencies, in fact "Mode 2" appears to resemble the mission-oriented R\&D described above. The scholarly accounts of the "new context" of science and technology policy in nanotechnology overlook the longstanding prominence within US federal R\&D spending of these missionoriented R\&D programs. It is of course true that economic objectives now are more prominent within the NNI programs than was true of the R\&D programs of the National Institutes of Health or the Defense Department, but this difference concerns the nature rather than the existence of programmatic objectives that go beyond knowledge for knowledge's sake.

\section{What is new about nanotechnology in the US national innovation system?}

Although some of the claims for novelty in US nanotechnology R\&D and policy may be overstated, nanotechnology R\&D programs and policies do include new features that pose

Footnote 2 continued

for 2003-2004 show that in none of these nations does "nonmission" R\&D account for as much as 50\% of central-government R\&D spending, and in most of them, "mission-oriented" R\&D spending accounts for more than $60 \%$ of the public R\&D budget. The "mission-oriented" categories of R\&D spending, chosen to make these national data as comparable as possible, are defense, space exploration; energy, agriculture, industrial technology development, and health.

${ }^{3}$ Martin (2003, p. 9) highlights “....several essential characteristics of the [Vannevar] Bush social contract. First, it implied a high level of autonomy for science. Second, decisions on which areas of science should be funded should be left to scientists. It therefore brought about the institutionalization of the peer-review system to allocate resources, a system used before the Second World War by private foundations that supported research. Third, it was premised on the belief that basic research was best done in universities (rather than government or company laboratories)."

4 Indeed, at least one important postwar program of defense-related R\&D, the U.S. Defense Advanced Research Projects Agency's (DARPA) initiative to create academic "centers of excellence" in the embryonic field of computer science, peer review played a minimal role (see Langlois and Mowery 1996). 
challenges for the future performance of the US innovation system. These novel features include (1) the intensive patenting of nanotechnology discoveries, including many that are well "upstream" from commercial application; (2) the intensive patenting of nanotechnology discoveries by US research universities that seek to "transfer" these research advances to commercial application through licensing; and (3) the emergence of a vertically specialized structure for innovation in nanotechnology at an early stage of the technology's development.

These three novel elements are closely related to one another, and reflect the fact that the development of nanotechnology, unlike IT, has from its inception taken place in an environment of strong patentholder rights, the so-called "pro-patent era" in US intellectual property rights policy that dates back to the early 1980s (see Mowery 2010c, for further discussion). The consequences of the "pro-patent era" for US economic performance have been the subject of a wide-ranging and inconclusive debate since the early 1990s. One consequence on which there is little debate is the surge in patenting during 1980-2005. Between 1967 and 1984, US patent applications grew by roughly $0.3 \%$ per year; after 1984, the rate of growth increased to nearly $7 \%$ per annum (Hall 2004). ${ }^{5}$

\subsection{Nanotechnology R\&D in the "pro-patent era"}

As an emergent technology in the "pro-patent era," nanotechnology R\&D has been characterized by extensive patenting, and some observers argue that these patents now cover scientific concepts, rather than innovations that are nearer to commercialization. This characteristic of nanotechnology contrasts with earlier postwar technological innovations, such as semiconductors, computer hardware, or computer software, all of which faced an intellectual property-rights policy environment that was more hostile to patentholder rights. In addition, a combination of federal antitrust policy actions affecting producers of computers and semiconductor components, as well as uncertainty over the patentability of life forms, ${ }^{6}$ meant that in most of these previous major technological clusters, intellectual property rights were both weaker and more uncertain in the earliest years of the technologies' development.

As Lemley (2005) has noted, the development of nanotechnology presents an interesting social experiment on the effects of extensive patenting on foundational technological or scientific advances in the early years of development of a technology:

In most other fields of invention over the past century in what we might think of as "enabling" technologies-computer hardware, software, the Internet, even biotechnology - the basic building blocks of the field were unpatented, either because they were created by government or university scientists with no interest in patents, or through mistake, or because the government compelled licensing of the patents, or because the patents were ultimately invalidated. $(2005$, p. 7)

\footnotetext{
${ }^{5}$ Other scholars have suggested that this surge in patent applications, particularly those involving relatively new fields of inventive activity such as computer software, has taxed the review capabilities of the U.S. Patent Office, leading to an increase in low-quality patents (Merges 1999).

${ }^{6}$ Although biotechnology and biomedical R\&D generally now are characterized by strong patents, as I note below, in its early years, biotechnology was characterized by considerable uncertainty over the patentability of key research advances. As a result, foundational biotechnology patents, including the Cohen-Boyer and Axel patents, were licensed nonexclusively and at relatively modest royalty rates (see Mowery et al. 2004). A March 2010 federal court decision, coupled with the filing in late October 2010 by the U.S. Justice Department of a "friend of the court" brief in connection with an appeal of this decision that opposes the patentability of human genes, may once again create significant uncertainty about the strength of patents in some fields of biotechnology (see Pollack 2010).
} 
Although nanotechnology patenting has been extensive, few if any of the major nanotechnology patents have been challenged in court, nor have infringement actions been resolved on terms that establish the value of these patents. Uncertainty about the value of nanotechnology patents nevertheless has not prevented rapid growth in such patenting. The share of patenting by US-based entities accounted for by the "nanotechnology" patent class, 977 , which was created by the USPTO in 1975, grew from nothing to slightly more than $0.4 \%$ by $2001^{7}$

The rapid growth in nanotechnology patenting has been driven in part by US universities, another characteristic of nanotechnology R\&D that is both novel and potentially challenging for the US national innovation system. US universities, which accounted for less than $2 \%$ of all US patents during 1975-2002, hold more than $15 \%$ of all US patents in nanotechnology. Conversely, US corporations' share of nanotechnology patents is smaller than their share of overall US patents.

\section{2 "Post-academic research" in US universities before and after the Bayh-Dole Act}

A central part of the argument made by advocates of the "transformation" in US universities' role within the US national innovation system with the rise of nanotechnology concerns the Bayh-Dole Act of 1980 and the subsequent expansion of university patenting. Although US universities have increased their patenting and licensing activities since the 1980 Act, this shift in the characteristics of university research in fact represents an extension in a longstanding trend, rather than a transformative event.

Collaboration between university and industrial researchers, combined with the focus of many US university researchers on scientific problems with important industrial or agricultural applications, meant that a number of US universities patented faculty inventions throughout the twentieth century. The decade of the 1970s, as much as or more so than the 1980 s, represented a watershed in the growth of US university patenting and licensing. US universities expanded their patenting, especially in biomedical fields, and assumed a more prominent role in managing their patenting and licensing activities (see Mowery and Sampat 2001). Private universities expanded their patenting and licensing during this decade, and the share of biomedical technologies within US university patents began to grow in 1972, well before the passage of the Bayh-Dole Act in 1980.

Having assumed responsibility for management of their patenting and licensing activities, US universities began to chafe against the restrictions on their licensing activities imposed by some federal research funding agencies (notably, the U.S. National Institutes of Health, NIH). Lobbying by US research universities to reduce federal oversight of licensing was an important factor behind the passage of the Bayh-Dole Act in 1980. The Act is as much an effect as a cause of expanded patenting and licensing by US universities during the post-1960 period.

How did the Bayh-Dole Act affect patenting by US universities? Universities increased their share of patenting from less than $0.3 \%$ in 1963 to nearly $4 \%$ by 1999 , but the rate of growth in this share begins to accelerate before rather than after 1980. Another issue of interest in academic patenting is the distribution among technology fields of Dechenaux, E., Thursby, M. \& Thursby, J during the pre- and post-Bayh-Dole periods. Nonbiomedical university patents increased by $90 \%$ from the $1968-1970$ period to the $1978-1980$ period, but biomedical university patents increased by $295 \%$. Evidence cited in Mowery et al.

\footnotetext{
7 Since this patent class includes a number of patents that in earlier years would have been classified elsewhere, this measure of growth in the share of "nanotechnology" patents is somewhat overstated.
} 
(2004) reveals that gross licensing revenues for Columbia University, Stanford University, and the University of California system during the period after the passage of the BayhDole Act were dominated by a small number of patents. For each of these three universities, the "top 5" patents accounted for more than $65 \%$ of gross licensing revenues. These "top 5" patents were mainly biomedical inventions.

The dominance of US university licensing revenues since Bayh-Dole by licenses for biomedical patents reflects the unusual legal strength and economic value of patents in this field (see Levin et al. 1987). The significantly higher economic value of patents in these fields reflects the fact that they are very difficult to "invent around," as well as the tendency for one or a small number of patents to effectively cover all relevant aspects of a specific invention.

The legal and economic value of patents in biomedical technologies contrasts with their more limited effectiveness in other fields, notably information technology and electronics, where a given innovation draws on many different patents, the power of any single one of which to exclude imitators is much more uncertain. ${ }^{8}$ The more limited power of patents in these fields is reflected in their modest contributions to university licensing revenues. Surveys of industrial R\&D managers also indicate that patents per se play only a minor role as channels of knowledge transfer from academia to industry (Levin et al. 1987; Cohen et al. 2002) in fields other than pharmaceuticals or chemicals.

In light of the limited effectiveness of patents for licensing and technology transfer in fields outside of pharmaceuticals, chemicals, and biomedical technologies, academic patenting of nanotechnology inventions may be of secondary importance in technology transfer. Indeed, Mody's discussion (2006) of the development of probe microscopy, a critical innovation for nanotechnology R\&D, emphasizes the informal, interactive character of the collaborations between university and industry researchers that spawned the production of probe electron microscopes for application in university and industrial research. ${ }^{9}$ Patent licensing was of little importance in facilitating these interactions. Do the characteristics of nanotechnology $R \& D$ and innovation in other fields resemble those described by Mody, or is this interactive, informal pattern of collaboration unique to nanotechnology-related instrumentation? At least some senior managers at US firms, including managers of large-scale nanotechnology $\mathrm{R} \& \mathrm{D}$ programs, argue that university licensing policies impede industry-university collaboration (see Williams 2002). ${ }^{10}$

\footnotetext{
8 In their work on university-industry interactions in the biotechnology industry, Zucker and Darby (2005) and Zucker et al. (1998) emphasize the role of academic scientists collaborating or consulting with industrial researchers as a crucial channel of technology transfer, reflecting the "natural excludability" of early-stage biotechnology research advances, which involve a significant element of tacit knowledge that is not easily communicated through a licensing agreement.

9 Mody also criticizes the characterization of nanotechnology research as "post-academic" in terms similar to those used in this paper: "There was no golden age in which faculty operated independently of commerce, pursuing disinterested research. Knowledge-production in physics, engineering, and chemistry was always aided by academic consulting and the exchanging of personnel and ideas. The oft-criticized commercialism of the "biotech revolution" merely extended long-standing entrepreneurial practices into molecular biology" (2006, p. 80).

10 "Largely as a result of the lack of federal funding for research, American Universities have become extremely aggressive in their attempts to raise funding from large corporations ... Large US based corporations have become so disheartened and disgusted with the situation they are now working with foreign universities, especially the elite institutions in France, Russia and China, which are more than willing to offer extremely favorable intellectual property terms." (R. Stanley Williams, HP Labs, September 17, 2002; statement reproduced at http://www.memagazine.org/contents/current/webonly/webex319.html; accessed April 2, 2005).
} 
The broader effects of patenting embryonic scientific discoveries on the progress of basic scientific research also are uncertain. Will university intellectual property regulations interfere with the free flow and exchange of information and research materials, either through patenting of inputs to science or through other restrictions on information exchange ${ }^{11}$

A substantial body of work has examined the effects of academic patenting on the flow of scientific information among researchers (Blumenthal et al. 1997; Campbell et al. 2002; Murray and Stern 2007; Sampat 2004; Walsh et al. 2005; Lei et al. 2009), and has reached a mixed verdict. On the one hand, publications covering discoveries that eventually are patented appear to experience a drop in citations after the patents issue, suggesting that the patents cause other researchers to direct their effort elsewhere. On the other hand, academic researchers report that they are (purposefully or otherwise) unaware of the existence of patents on a given area of research. What then appears to cause academic researchers to shift their research away from topics for which patents have been issued to other researchers?

One explanation for these apparently conflicting findings hypothesizes that researchers are less likely to obtain essential research materials (biological materials or research tools) from other researchers when these materials are covered by patents. An instrument of growing importance in the governance of transfers of materials among researchers in both academia and industry is the "Materials Transfer Agreement" (MTA). MTAs are agreements among researchers governing the transfer and exchange of biological materials used in research. Their complexity and detailed provisions vary, but many of them include provisions for "reach-through" royalties on patents resulting from the use of the materials, and other such agreements limit the ability of the recipient of the materials to patent or license the results of research using the materials.

Historically, materials exchanges were governed by little more than a letter from the source accompanying the materials, requesting acknowledgement and in some cases asking that the materials not be passed on to third parties (see McCain 1991). The more elaborate MTAs used in contemporary materials exchanges appear to be a byproduct of the post-1980 surge in academic patenting. ${ }^{12}$ MTAs are used widely by both industry and academic researchers, and cover exchanges of materials within industry, within academia, and between industry and academia. MTAs are especially widespread in biomedical research, an area in which nanotechnology researchers are increasingly active.

According to Walsh et al. (2007) academic researchers reported that denial by other researchers of requests for materials did impede their work. But this study provides no information on the extent to which MTAs typically covered transfers of research materials associated with patented research results. Walsh et al. (2007) also reported that

\footnotetext{
11 Zucker and Darby (2005) argue that the importance for nanotechnology of innovation in instruments that were commercially available within 5 years of their development has reduced the "natural excludability" associated with nanotechnology, in contrast to biotechnology. They note, however, that "...the uses that these instruments are being put [sic] involves areas which are very imperfectly understood and other new methods of inventing may be at least as important as scanning probe microscopy. Thus the involvement of the inventing scientists may be very valuable in commercialization, and we note that many of the best nano scientists and engineers maintain their academic positions and research programs while co-founding and guiding new entrants or continuing relationships collaborating at the bench-science level with scientists from incumbent firms." (pp. 161-162).

12 Respondents to the survey of University of California agricultural biotechnology researchers by Lei et al. (2009) report "moderately more" use of MTAs than in 1999.
} 
more than one-quarter of the MTAs used by researchers took more than 1 month to finalize. Data from the University of California, Davis technology transfer office indicate that MTAs with private-sector entities (either MTAs requesting materials from privatesector researchers or MTAs that furnish UC Davis research materials to industrial researchers) especially likely to incur delays. ${ }^{13}$ If patented research findings are more commonly associated with the use of MTAs on exchanges of these or related research materials, the conflicting results on the impediments to scientific research created by patents might be reconciled. With the exception of one preliminary analysis of this possibility (Mowery and Ziedonis 2007), the correlation between patents and MTAs has not been examined.

The increased salience and complexity of MTAs within biomedical research indicate a potential for the growing assertion by universities of intellectual property rights to affect the disposition of inputs to, as opposed to the results of, scientific research. Considerable work remains to be done on the effects of MTAs on scientific communication, and on the relationship between patenting of university research advances and the use of MTAs. Little if anything is known about the prevalence of MTAs in nanotechnology research, although the importance of access to specialized instrumentation and materials in the field suggests that they could play a significant role in the future. In addition, much recent US commercial R\&D in nanotechnology has focused on biomedical applications, further increasing the likelihood that MTAs affecting nanotechnology materials could affect research in this area. ${ }^{14}$

\subsection{Vertical specialization in nanotechnology innovation}

The structure of industrial innovation in nanotechnology in the "pro-patent era" contrasts with that of innovation in other US post-1945 "new industries," particularly semiconductors and computers. Innovation in the early development of these industries was dominated by vertically integrated industrial enterprises that conducted fundamental research, developed new products, and manufactured these new products within a single organization (in many cases, producing the equipment needed to manufacture semiconductors or computer components). The current organization of commercial nanotechnology innovation, however, resembles that of biotechnology. Firms specializing in research and very early-stage development (often, spinoffs from university laboratories) seek to license their products to established producers of related products in pharmaceuticals, medical equipment, or materials. Nanotechnology innovation involves contractual and collaborative relationships among a number of "vertically specialized" firms that each specialize in one segment of the overall process of commercial innovation.

The similarities between the industrial structure of nanotechnology and biotechnology innovation reflect the fact that in both sectors, universities play a prominent role as sources of technological advances that are licensed, and university-based spinoff firms are an

\footnotetext{
13 These data exclude MTAs that are never finalized, and that failure in negotiations is also more likely for materials transfers to or from private-sector laboratories.

14 A recent OECD study (2007) found that the United States accounted for a disproportionate share of biomedical patent activity in nanotechnology, reflecting the abundance of research funding from the U.S. National Institutes of Health and the profitable domestic market for new medical devices and drugs in the United States.
} 
important source of entry into the industry. ${ }^{15}$ The strong intellectual property-rights environment characteristic of the current period favors the growth of "markets for technology," in which strong IP rights favor the use of contracts and markets for collaboration (Arora et al. 2001).

Economists long have emphasized the efficiency gains associated with firm-level specialization, and at least some scholars have argued that specialization leads to higher levels of innovative performance in vertically specialized industries. ${ }^{16}$ But there are important countervailing factors that are unique to the innovation process, such as severe uncertainty about the true value or commercial prospects of a given piece of intellectual property, the potential for misrepresentation or opportunistic behavior within arms-length contracting relationships, and the inability of contracts to deal with a wide array of unanticipated contingencies in the process of taking fundamental research to the point of commercialization.

All of these factors may undercut the innovation-related efficiency gains of vertically specialized industries, and these countervailing factors are likely to be more significant and pervasive in the early stages of a technology's development. Not only are technological and commercial uncertainty likely to be greatest in these early stages, but the parties to contractual agreements in the innovation process are likely to be less aware of the presence and implications of such uncertainties, and therefore less proficient at managing them. With the development of an industry or technology, these underlying uncertainties may be reduced and the ability of firms, inventors, and entrepreneurs to manage them may improve as a result of experience.

Most of the industries within IT now have shifted to a vertically specialized structurein semiconductors, specialist firms are separately responsible for design of semiconductor components, while others specialize in production. The emergence of specialist producers of computer software and hardware has produced a similar structure of vertical specialization in the computer industry, which formerly relied on firms "bundling" software and hardware. The development of a vertically specialized industry structure in IT was associated with the emergence of "modular architectures," i.e., technological subsystems that have relatively stable interfaces with others, such as software and hardware within computers. But no similarly modular architecture has yet emerged within nanotechnology, and as a result, collaboration among specialized firms in innovation is likely to remain challenging.

It is too early to reach any conclusions about the effects on innovative performance of the vertically specialized structure that characterizes nanotechnology $R \& D$ at present. Nevertheless, the recent experience of the US biotechnology industry presents some cautionary evidence. As Cockburn $(2004,2006)$ has noted, vertical specialization within US biotechnology thus far has failed to produce either significant overall returns for shareholders in biotechnology firms or a dramatic increase in the rate of new drug introduction by the large pharmaceutical firms that are primarily responsible for developing the

\footnotetext{
15 Numerous scholars, most notably Zucker and Darby (2005), Zucker et al. (2007) and Darby and Zucker (2005), have commented on the similarities between biotechnology and nanotechnology-for a survey of this work, see Huang et al. (2010). But this extensive literature has devoted little attention to the implications of vertical specialization for the commercial development of nanotechnology applications.

16 See Arora et al. (2001, p. 114): “...we strongly believe that such markets [for technology] can have substantial benefits by encouraging more extensive use of existing technologies and an increase in the rate of technological change...".
} 
drugs that biotechnology "R\&D boutiques" specialize in discovering. ${ }^{17}$ The number of new drugs approved annually by the US Food and Drug Administration for commercial use declined significantly during 1994-2004, a period characterized by considerable expansion in the use by pharmaceuticals firms of alliances and vertical licensing arrangements, in the face of much higher levels of R\&D spending within the industry (Berenson 2006).

The validity of these measures of innovation in the pharmaceutical industry is subject to debate (e.g., counts of the number of new drugs approved for marketing say little or nothing about the therapeutic value or economic significance of individual drugs), and numerous other factors beyond the vertically specialized structure that has emerged within US pharmaceuticals play important roles in these trends. Nonetheless, the fact remains that the growth of such a vertically specialized structure is not associated with a significant increase in the (imperfectly measured) rate of innovation.

The emergence of a vertically specialized structure of innovation in nanotechnology at such an early point in the development of this technology reflects the interaction of several novel features of the environment surrounding innovation in nanotechnology-the changing role of universities as sources of patented technologies for license is closely linked with the broader shifts in US intellectual property-rights policy that were discussed earlier. Whether and how entrepreneurs and innovators will be able to manage the complexities of a vertically specialized structure for innovation remains to be seen.

\section{Conclusion}

Forecasting the pace and economic effects of the future development of nanotechnology is hazardous, as the 2006 report of the National Research Council's review of the NNI noted. ${ }^{18}$ Instead, this paper has examined the ways (if any) in which the current institutional structure and public policies within the evolving nanotechnology R\&D enterprise represent a departure from longstanding characteristics of the post-1945 US national

\footnotetext{
17 "In general, one can be optimistic about efficiency being raised by increased vertical specialization in industries where competition is high among horizontal segments, where specialization reduces costs, where vertical coordination is relatively unimportant, where prices for the upstream technology accurately reflect marginal opportunity costs, and where bargaining and contracting are easy and effective.

Is this the case in early-stage pharmaceutical research? Several aspects of the economic relationship between biotech tool companies and Big Pharma suggest otherwise. Muted price signals from end users, high levels of uncertainty, high transaction costs and serious contracting problems, and limited competition in specific areas of technology all make finding an efficient vertically dis-integrated solution less likely....

For economists, excess entry, high failure rates, and the inability to make profits are signs of overinvestment, "wrong prices," and misallocation of resources. Anecdotal evidence and the relatively low average stock market returns from biotechnology companies over the past few decades support this pessimistic view." (Cockburn, 2004, p. 20).

18 “...efforts to analyze R\&D's economic impact in other areas have often been hindered by a lack of metrics and lack of a comprehensive empirical framework...Assessing economic impact is also challenging because of the complexity of forces that drive economic growth and the inherent uncertainty surrounding outcomes observed at a particular point in time. Moreover, in general the timescales from research-based discovery to commercialization of technologies are long, often 20 years or more, and as an enabling technology, nanotechnology in particular is still in its infancy. The timescales over which the cumulative benefits of nanoscale $R \& D$ will become apparent will vary, depending on the nature of individual industries and products and the kinds of developmental research and testing required, such as clinical trials. Also, the investment needed for change and the availability of sustained investment for long-term gain will be determining factors. Although it is clear that nanotechnology will have an impact on many applications and industries, how to measure its economic impact is not now clear." (National Research Council 2006, pp. 61-62).
} 
innovation system. Although I disagree with the current characterizations that claim that this institutional emergent structure is novel, several important elements of the current structure of nanotechnology $R \& D$ contrast with those of previous postwar innovations, most notably semiconductors and computers.

One area of similarity among these innovations is in the characteristics of and motives for federal-government R\&D funding. Although the emphasis in federally funded nanotechnology $R \& D$ on economic objectives may represent a change, the focus on specific policy objectives, as well as the cross-institutional collaboration that federal R\&D programs encourage, is not novel.

Perhaps the most significant feature distinguishing nanotechnology from the IT-related innovations noted above is the transformation in the intellectual property rights environment that has occurred since 1980. Patents have been obtained by both academic and industrial researchers on a broad array of fundamental advances in nanotechnology in the very early stages of this technology's development, unlike the situation at a similarly early stage in the development of IT or even biotechnology. In spite of considerable evidence that patents and licenses may be ineffective mechanisms for collaboration and technology transfer in fields other than chemistry and the biomedical sciences, US universities have intensified their reliance on patents in nanotechnology R\&D. Moreover, if the extensive use of patents by academic researchers in nanotechnology expands their use of Materials Transfer Agreements, especially in nanotechnology research related to the life sciences, additional impediments to the conduct of fundamental science in this new field of research could appear.

Such impediments to research and technology development can be reduced through changes in US universities' technology licensing policies. Universities should develop policies that recognize the differences among research fields in the strength of patents and the benefits of patent licensing for technology transfer in different fields. Although some universities have begun to examine such policies, there has been surprising little experimentation with alternatives to the patent-centered model of technology transfer in the 30 years since the passage of the Bayh-Dole Act. In addition, universities must ensure that MTAs facilitate, and do not restrict, the flow of research tools and materials among their scientists.

Change in the characteristics of university-industry interaction and intellectual property policy have combined to produce a structure for industrial innovation that contrasts with that observed in the early years of the IT sector and resembles more closely the structure that has emerged in biotechnology. This vertically specialized structure of innovation in a technology that is in its early stages of development and subject to enormous technical and commercial uncertainties, combined with the difficulties of writing contracts that can deal with unforeseen contingencies and opportunistic behavior, may have impeded the productivity of drug discovery and development within biotechnology. Whether vertical specialization in nanotechnology innovation will prove similarly difficult to manage is another area of uncertainty, albeit one with important implications for the future.

It may well be the case that in both biotechnology-based drug development and the development of commercial applications of nanotechnology, alternatives to the current vertically specialized industry structures will be needed. Market forces and experimentation with alternative organizational forms may support the development of alternatives to vertical specialization. The evolution of public policy, however, may be less responsive to market forces. And as I have noted above, a central factor in the emergence of the innovation system within which nanotechnology $R \& D$ is evolving in both the US and 
global economies is the stronger formal intellectual property rights environment. The expansion of patenting into the realm of scientific research has the potential for creating significant impediments to the advance of fundamental research in this field. Both patents and potentially, MTAs can limit the flow of knowledge and results among scientists in academia and industry, although the extent and significance of any such impediments remain uncertain at present.

It is important for the successful exploitation of the scientific advances represented by nanotechnology that federal funding agencies participating in the NNI develop policies that support the free flow of scientific information among US and foreign researchers. In considering such policies, the NNI can benefit from the experiences of the US National Institutes of Health, the leading federal supporter of basic biomedical research. For more than a decade, the NIH has experimented with policies seeking to prevent the growth of various formal intellectual-property instruments, including patents and MTAs, from creating serious frictions in the biomedical research enterprise. ${ }^{19} \mathrm{NIH}$ is an important funder of NNI R\&D, but its experience in developing policies to reduce impediments to the flow of scientific knowledge among biomedical researchers should be exploited for the development of NNI policies related to intellectual property and the sharing of research results and materials. NNI would do well to try to summarize and exploit the "lessons" of these NIH policies. Such an effort could accelerate scientific progress and potentially, commercial applications in this important new field of science.

Acknowledgments This paper is based on my keynote address to the inaugural meeting of the Society for the Study of Nanotechnology and Emerging Technologies, Seattle, WA, September 10, 2010. I am grateful to two anonymous referees for comments. Research for this paper was supported in part by the U.S. National Science Foundation (Cooperative Agreement \#0531184).

Open Access This article is distributed under the terms of the Creative Commons Attribution Noncommercial License which permits any noncommercial use, distribution, and reproduction in any medium, provided the original author(s) and source are credited.

\section{References}

Arora, A., Fosfuri, A., \& Gambardella, A. (2001). Markets for technology. Cambridge, MA: MIT Press.

Arrow, K. J. (1962). Economic welfare and the allocation of resources for R\&D. In R. Nelson (Ed.), The rate \& direction of inventive activity. Princeton, NJ: Princeton University Press.

Berenson, A. (January 11, 2006). Drugs in 2005: Much promise, little payoff. New York Times.

Blumenthal, D., Campbell, E. G., Anderson, M., Causino, N., \& Louis, K. (1997). Withholding research results in academic life science: Evidence from a national survey of faculty. Journal of the American Medical Association, 277, 1224-1229.

Bush, V. (1945). Science: The endless frontier. Washington, DC: U.S. Government Printing Office.

Campbell, E. G., Clarridge, B. R., Gokhale, M., Birenbaum, L., Hilgartner, S., Holtzman, M., et al. (2002). Data withholding in academic genetics: Evidence from a national survey. Journal of the American Medical Association, 287, 473-480.

Cockburn, I. M. (2004). The changing structure of the pharmaceutical industry. Health Affairs, 23, 10-22.

Cockburn, I. M. (2006). Is the pharmaceutical industry in a productivity crisis? In A. B. Jaffe, J. Lerner, \& S. Stern (Eds.), Innovation Policy and the Economy 7, 1-32.

\footnotetext{
19 Among other things, the NIH developed a "Uniform Biological Materials Transfer Agreement" for use by academic research institutions that is intended to facilitate the exchange of materials among researchers. The 2006 National Research Council report on intellectual property issues in human genomics provides a useful summary of NIH efforts to promote free flows of scientific information among researchers in this field (National Research Council, 2006b).
} 
Cohen, W. M., Nelson, R. R., \& Walsh, J. P. (2002). Links and impacts: The influence of public research on industrial R\&D. Management Science, 48, 1-23.

Darby, M. R., \& Zucker, L. G. (2005). Grilichesian breakthroughs: Invention of methods of inventing and firm entry in nanotechnology. Annales d'Economie et de Statistique, 79-80, 143-164.

Etzkowitz, H. (2008). The triple helix: University-industry-government innovation in action. New York: Routledge.

Freeman, C. (1987). Technology policy and economic performance: Lessons from Japan. London: Pinter.

Gibbons, M., Limoges, C., Nowotny, H., Schwartzman, S., Scott, P., \& Trow, M. (1994). The new production of knowledge. New York: Sage.

Guston, D. H., \& Keniston, K. (1994). Introduction. In D. H. Guston \& K. Keniston (Eds.), The fragile contract. Cambridge, MA: MIT Press.

Hall, B. H. (2004). Exploring the patent explosion. NBER Working Paper \#10605.

Huang, C., Notten, A., \& Rasters, N. (2010). Nanoscience and technology publications and patents: A review of social science studies and search strategies. Journal of Technology Transfer (forthcoming).

Johnson, A. (2004). The end of pure science: Science policy from Bayh-Dole to the NNI. In D. Baird \& A. Nordmann (Eds.), Discovering the nanoscale. IOS Press: Amsterdam.

Langlois, R. N., \& Mowery, D. C. (1996). The federal government role in the development of the U.S. software industry. In D. C. Mowery (Ed.), The international computer software industry: A comparative study of industry evolution and structure. New York: Oxford University Press.

Lei, Z., Juneja, R., \& Wright, B. (2009). Patents versus patenting: implications of intellectual property protection for biological research. Nature Biotechnology, 27, 36-40.

Lemley, M. A. (2005). Patenting nanotechnology. Working paper \#304, Olin Program in Law \& Economics, Stanford Law School.

Levin, R. C., Klevorick, A., Nelson, R. R., \& Winter, S. (1987). Appropriating the returns from industrial research and development. Brookings Papers on Economic Activity, 3, 783-820.

Lundvall, B. - $\AA$. (1992). National systems of innovation: Towards a theory of innovation and interactive learning. London: Pinter.

Martin, B. R. (2003). The changing social contract for science and the evolution of the university. In A. Geuna, A. J. Salter, \& W. E. Steinmueller (Eds.), Science and innovation: Rethinking the rationales for funding and governance. Cheltenham, UK: Elgar.

McCain, K. W. (1991). Communication, competition, and secrecy: The production and dissemination of research-related information in genetics. Science, Technology, \& Human Values, 16, 491-516.

McCray, W. P. (2005). Will small be beautiful? Making policies for our nanotech future. History and Technology, 21, 177-203.

Merges, R. P. (1999). As many as six impossible patents before breakfast: Property rights for business concepts and patent system reform. Berkeley High Technology Law Journal, 14, 577-615.

Mody, C. C. M. (2006). Corporations, universities, and instrumental communities: Commercializing probe microscopy, 1981-1996. Technology and Culture, 47, 56-80.

Mowery, D. C. (2010a). Military R\&D and innovation. In B. H. Hall \& N. Rosenberg (Eds.), Handbook of the economics of innovation. Amsterdam: North-Holland.

Mowery, D. C. (2010b). Federal policy and the development of semiconductors, computer hardware, and computer software: A policy model for climate-change R\&D? In R. Henderson \& R. Newell (Eds.), Accelerating innovation: Lessons from federal policy. Cambridge, MA: MIT Press for NBER (forthcoming).

Mowery, D. C. (2010c). IPR and U.S. economic catch-up. In H. Odagiri, A. Goto, A. Sunami, \& R. Nelson (Eds.), Intellectual property rights and catch-up. Oxford, UK: Oxford University Press.

Mowery, D. C., Nelson, R. R., \& Martin, B. (2009). Technology policy and global warming. Working paper, U.K. National Endowment for Science, Technology and the Arts.

Mowery, D. C., Nelson, R. R., Sampat, B. N., \& Ziedonis, A. A. (2004). 'Ivory Tower' and industrial innovation: University-industry technology transfer before and after the Bayh-Dole Act. Stanford, CA: Stanford University Press.

Mowery, D. C., \& Sampat, B. N. (2001). Patenting and Licensing University inventions: Lessons from the history of the research corporation. Industrial and Corporate Change, 10, 317-355.

Mowery, D. C., \& Ziedonis, A. (2007). Academic patents and materials transfer agreements: Substitutes or Complements? Journal of Technology Transfer, 32, 157-172.

Murray, F., \& Stern, S. (2007). Do formal intellectual property rights hinder the free flow of scientific knowledge? A test of the anti-commons hypothesis. Journal of Economic Behavior and Organization, $63,648-687$.

National Research Council. (2006). Reaping the benefits of genomic and proteomic research: Intellectual property rights, innovation, and public health. Washington, DC: National Academies Press. 
National Research Council, Committee to Review the National Nanotechnology Initiative. (2006). A matter of size: Triennial review of the national nanotechnology initiative. Washington, DC: National Academies Press.

National Science Board. (2006). Science and engineering indicators: 2006. Washington, DC: National Science Board.

Nelson, R. R. (1959). The simple economics of basic research. Journal of Political Economy, 67, 297-306.

Nelson, R. R. (Ed.). (1993). National innovation systems: A comparative analysis. Oxford: Oxford University Press.

OECD. (2007). Capturing nanotechnology's current state of development via analysis of patents. STI Working Paper 2007/4.

Pollack, A. (2010). Gene patent ruling raises questions for industry. New York Times, November 1, p. C1.

Sampat, B. N. (2004). Genomic patenting by academic researchers: Bad for science? Working Paper.

Walsh, J. P., Cho, C. \& Cohen, W. M. (September 23, 2005). The view from the bench: Patents, material transfers and biomedical research. Science, pp. 2002-2003.

Walsh, J. P., Cohen, W. M., \& Cho, M. (2007). Where excludability matters: Material versus intellectual property in academic biomedical research. Research Policy, 36, 1184-1203.

Williams, R. S. (2002). Written testimony of R. Stanley Williams, HP fellow, on behalf of the HewlettPackard Company before the U.S. Senate Subcommittee on Science, Technology, and Space, September 17; statement reproduced at http://www.memagazine.org/contents/current/webonly/webex319. html. Accessed April 2, 2005.

Zucker, L. G., \& Darby, M. R. (2005). Socioeconomic impact of nanoscale science: Initial results and Nanobank. NBER Working Paper 11181.

Zucker, L. G., Darby, M. R., \& Brewer, M. (1998). Intellectual human capital and the birth of U.S. biotechnology enterprises. American Economic Review, 88, 290-306.

Zucker, L. G., Darby, M. R., Furner, J., Liu, R. C., \& Ma, H. (2007). Minerva unbound: Knowledge stocks, knowledge flows and new knowledge production. Research Policy, 36, 850-863. 